\title{
SISTEM PENILAIAN KARAKTER BERDASARKAN KESANTUNAN BERBAHASA DI PERGURUAN TINGGI
}

\author{
Safinatul Hasanah Harahap \\ Universitas Negeri Medan \\ finahrp@gmail.com
}

\begin{abstract}
Abstrak
Karakter merupakan sikap dan perilaku seseorang yang dapat diubah dan ditingkatkan. Hal tersebut dapat dilakukan melalui proses penilaian dengan sistem yang tepat. Penelitian ini bertujuan mendeskripsikan sistem penilaian karakter berdasarkan kesantunan berbahasa. Metode penelitian yang digunakan adalah metode deskriptif dengan pendekatan kualitatif. Sumber data penelitian adalah Prodi Pendidikan Bahasa dan Sastra Indonesia Universitas Negeri Medan. Teknik pengumpulan data yang digunakan dalam penelitian adalah teknik dokumentasi, angket, dan wawancara. Hasil penelitian yang diperoleh bahwa nilai-nilai karakter yang dinilai dan diterapkan kepada setiap mahasiswa ada sepuluh, yaitu: etika berkomunikasi (sopan dan santun), kejujuran, tanggung jawab, kerja sama, ketangguhan, kepedulian, kedisiplinan, ketekunan, kemandirian, dan keberinisiatifan. Kesantunan termasuk dalam nilai etika berkomunikasi. Penilaian terhadap kesantunan berbahasa tidak memiliki indikator yang sama pada setiap dosen. Dari sudut pandang mahasiswa, diperoleh data bahwa mahasiswa yang mengungkapkan mendapat DPNA atau KHS yang berisi penilaian pembelajaran sebanyak 91,53\%, tidak memperoleh lembaran khusus untuk menilai kesantunan sebanyak 71,19\%, memperoleh penilaian sikap dalam bentuk angka 45,76\%, memperoleh penilaian kesantunan dalam bentuk deskripsi sebanyak 44,07\%, tidak pernah mendapat lembar isian yang berisi kesantunan berbahasa kurang lebih sebanyak 50\%, pernah berdiskusi dengan dosen mengenai cara berbicara dengan orang lain dan menuliskan pesan di telepon genggam kurang lebih sebanyak $50 \%$.
\end{abstract}

Kata Kunci: sistem penilaian, nilai-nilai karakter, kesantunan berbahasa

\section{A. Pendahuluan}

Karakter merupakan sikap dan perilaku yang menjadi karakteristik dan kepribadian seseorang dalam dirinya. Mulyasa (2011, hlm. 5) mengungkapkan bahwa karakter merupakan cerminan dari kepribadian jika ditinjau dari aspek kepribadian. Kepribadian yang berada dalam diri seseorang dapat terlihat melalui karakter yang ditunjukkan. Karakter yang diharapkan adalah karakter yang baik. Baik buruknya sebuah karakter bergantung pada budaya dan filosofi wilayah setempat karena adanya nilai-nilai yang dianut sesuai dengan pandangan masyarakat tertentu. 
Nilai baik buruk terhadap sikap maupun tindakan seseorang memiliki parameter tersendiri sesuai dengan budaya yang ada. Nilai karakter bangsa yang diharapkan pada peserta didik merupakan nilai-nilai yang dianggap penting untuk keutuhan bangsa. Pusat Pengembangan Kurikulum Kementerian Pendidikan Nasional (2010, hlm. 10) menjabarkan 18 nilai karakter bangsa, yaitu: religius, jujur, toleransi, disiplin, kerja keras, kreatif, mandiri, demokratis, rasa ingin tahu, semangat kebangsaan, cinta tanah air, menghargai prestasi, bersahabat/ komunikatif, cinta damai, gemar membaca, peduli lingkungan, peduli sosial, dan tanggung jawab. Sebahagian besar dari nilai karakter bangsa tersebut membutuhkan karakter sopan santun dalam perwujudannya.

Kesopanan dan kesantunan tidak hanya terdeskripsi dalam sikap, tetapi juga dalam bahasa yang digunakan. Kesantunan berbahasa merupakan nilai karakter yang harus dimiliki karena kesantunan berbahasa dapat memengaruhi hubungan sosial yang terjalin. Oleh karena itu, setiap orang harus memiliki sopan santun baik dalam berbicara maupun bersikap. Sauri (2006, hlm. 54) mengungkapkan bahwa orang yang berbahasa santun adalah orang yang tidak hanya dapat berbahasa dengan tepat, jelas, dan sopan, tetapi selaras dengan adat istiadat bahasa yang sudah menjadi tata tertib bahasa masyarakat, serta sesuai dengan peraturan bahasa.

Dewasa ini, kesantunan berbahasa menjadi permasalahan sosial baik di lingkungan sekolah, perguruan tinggi, masyarakat, maupun pemerintahan. Oleh karena itu, kurikulum pada sekolah dasar hingga menengah menilai karakter berdasarkan kesantunan berbahasa siswa dengan indikator penilaian yang telah ditetapkan. Hasil penilain tersebut menjadi pedoman bagi guru untuk mengevaluasi karakter siswa. Sistem penilaian karakter pada sekolah lebih terencana dan sistematis. Penilaian yang dilakukan juga disampaikan kepada siswa. Hal tersebut dilakukan agar terjadi perubahan sikap melalui proses diskusi dan konseling yang dilakukan oleh guru. Hal tersebut berbeda dengan perguruan tinggi yang tidak mengatur sistem penilaian karakter secara menyeluruh. Padahal permasalahan karakter, khususnya kesantunan berbahasa juga termasuk permasalahan yang terjadi pada tingkat mahasiswa.

Kesantunan berbahasa mahasiswa mejadi permasalahan umum. Keluhan yang terjadi mengenai kesantunan berbahasa mahasiswa terdapat dalam komunikasi langsung maupun komunikasi tidak langsung (via telepon genggam). Sebahagian mahasiswa tidak mampu bertutur sesuai dengan kaidah kesantunan berbahasa kepada dosen maupun rekan sejawat. Mahasiswa 
terkadang menyamakan cara berbicara dengan dosen dan rekan sejawat. Padahal dalam budaya Indonesia terdapat perbedaan cara berkomunikasi antara dosen dengan rekan sejawat.

Kesantuan berbahasa merupakan satu dari keterampilan dalam menggunakan bahasa Indonesia. Keterampilan menggunakan bahasa Indonesia yang baik wajib dimiliki oleh setiap orang, khususnya mahasiswa. Nugroho (2015, hlm. 1) menyatakan bahwa salah satu tanda mahasiswa menggunakan bahasa Indonesia yang baik adalah mahasiswa yang dapat berkomunikasi secara santun. Penggunaan bahasa santun memang sudah tidak bisa terlepas lagi dalam kehidupan kita sehari-hari di setiap situasi termasuk bahasa yang digunakan mahasiswa di ranah akademik.

Permasalahan kesantunan dan sistem penilaian berdasarkan kesantunan berbahasa merupakan hal yang penting pada tingkat perguruan tinggi. Oleh karena itu, seharusnya perguruan tinggi menerapkan sistem penilaian karakter berdasarkan kesantunan berbahasa juga. Sistem penilaian karakter berdasarkan kesantuanan berbahasa merupakan rangkaian unsur atau prosedur yang dirancang untuk menafsirkan atau memaknai data hasil pengukuran karakter berdasarkan kesantunan berbahasa dengan kriteria maupun aturan-atauran tertentu. Pada sistem penilaian tersebut terdapat beberapa karakteristik yang harus dipenuhi. Sutanta (2003, hlm. 4-6) mengungkapkan bahwa sistem memiliki sepuluh karakteristik, yaitu: mempunyai komponen, batas, lingkungan, penghubung, masukan, pengolahan, keluaran, sasaran dan tujuan, kendali, serta umpan balik.

\section{B. Metode Penelitian}

Penelitian ini menggunakan pedekatan kualitatif dengan metode deskriptif karena dalam penelitian ini bertujuan menggambarkan dan memaparkan isi dari objek yang akan diteliti. Best (dalam Sukardi, 2009, hlm. 157) mengungkapkan bahwa metode deskriptif adalah metode

penelitian yang bertujuan menggambarkan dan menginterpretasikan objek sesuai dengan kondisinya. Pada metode deskriptif objek penelitian dideskripsikan secara sistematis sesuai dengan fakta yang ada tanpa adanya kontrol dan manipulasi. Penelitian ini mendeskripsikan sistem penilaian karakter berdasarkan kesantunan berbahasa mahasiswa di perguruan tinggi yang menjadi sumber data. 
Sumber data penelitian adalah Prodi Pendidikan Bahasa dan Sastra Indonesia Universitas Negeri Medan. Universitas Negeri Medan (Unimed) merupakan perguruan tinggi yang memiliki motto "The Charahcter Building University". Motto tersebut menjadi salah satu alasan pemilihan unimed sebagai sumber data penelitian. Teknik pengumpulan data yang digunakan dalam penelitian adalah teknik dokumentasi, angket, dan wawancara. Teknik dokumentasi digunakan untuk mengumpulkan data berupa dokumen yang berkaitan dengan sistem penilaian karakter berdasarkan kesantunan berbahasa di perguruan tinggi. Dokumen yang dikumpulkan dalam penelitian adalah DPNA yang dibuat oleh dosen, KHS yang dimiliki oleh mahasiswa, dan pedoman penilaian karakter berdasarkan kesantunan berbahasa. Teknik kuesioner (angket) digunakan untuk mendapat gambaran mengenai sistem penilaian karakter berdasarkan kesantunan berbahasa mahasiswa dari sudut pandang mahasiswa. Teknik wawancara dilakukan untuk mendapatkan informasi mengenai sistem penilaian karakter berdasarkan kesantunan berbahasa yang dilakukan oleh dosen.

Langkah-langkah penelitian yang dilakukan melalui beberapa tahapan. Langkah-langkah tersebut dideskripsikan pada bagan berikut.

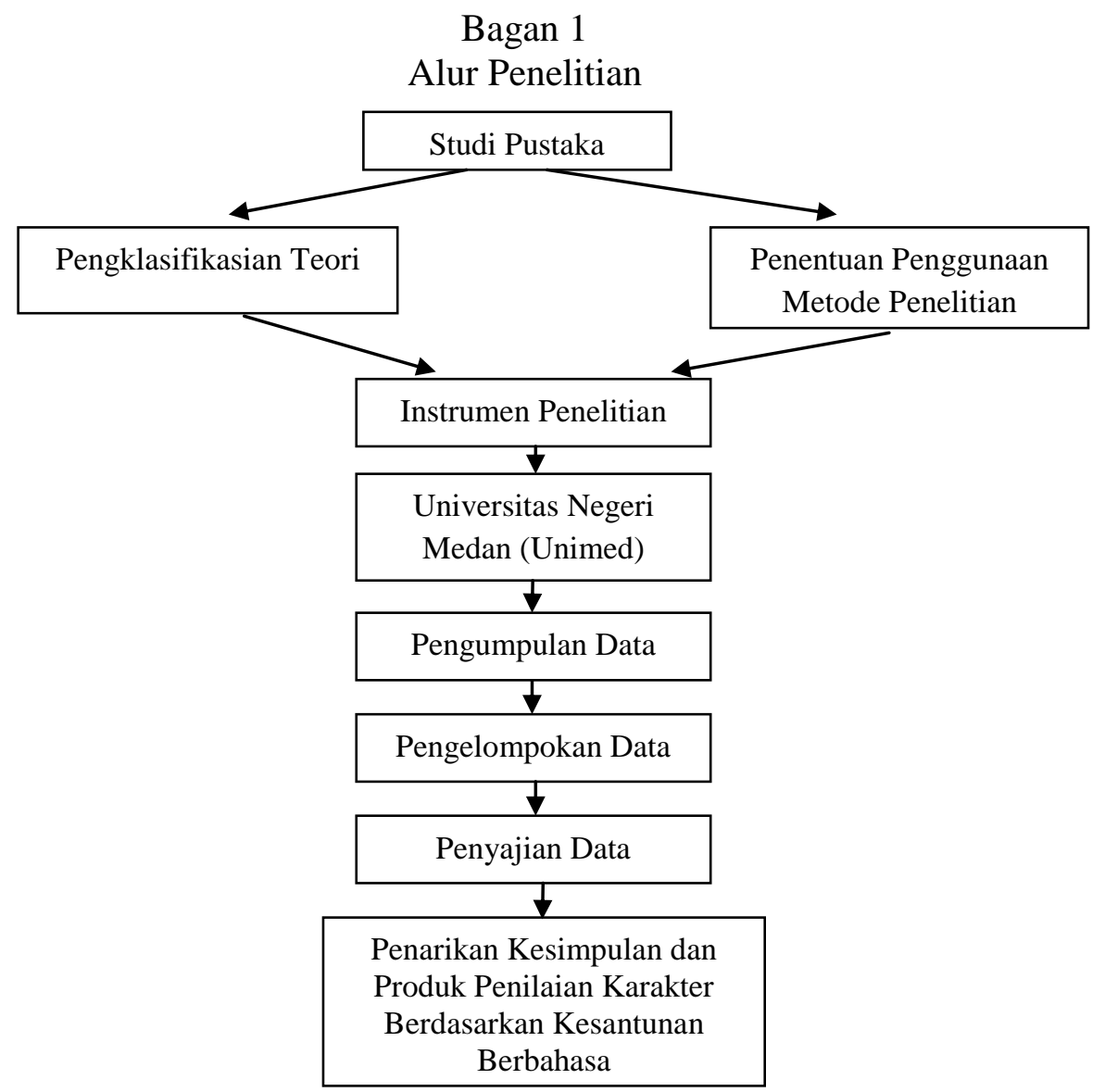




\section{Hasil dan Pembahasan}

Penelitian memperoleh beberapa hasil penelitian berupa data penelitian. Data tersebut dideskripsikan sesuai dengan fakta dan kajian teori yang terkait. Pemaparan tersebut diuraikan dalam pembahasan.

1. Hasil Penelitian

Hasil penelitian yang diperoleh adalah data dokumen, angket, dan wawancara. Data penelitian tersebut akan dirincikan sebagai berikut.

\section{a. Data Dokumentasi}

Dokumen yang dikumpulkan dalam penelitian adalah DPNA (1 lembar) yang dibuat oleh dosen, KHS (1 lembar) yang dimiliki oleh mahasiswa, dan pedoman penilaian karakter berdasarkan kesantunan berbahasa di Unimed. Dari ketiga dokumen dapat dideskripsikan mengenai sistem penilain karakter berdasarkan kesantunan berbahasa.

Berdasarkan ketiga dokumen, tampak bahwa Unimed melakukan penilaian sikap beradasarkan karakter. Nilai-nilai karakter yang dinilai dan diterapkan kepada setiap mahasiswa ada sepuluh, yaitu: etika berkomunikasi (sopan dan santun), kejujuran, tanggung jawab, kerja sama, ketangguhan, kepedulian, kedisiplinan, ketekunan, kemandirian, dan keberinisiatifan. Nilai kesantunan merupakan bagian dari nilai karakter yang telah ditetapkan Unimed, yaitu nilai etika berkomunikasi (sopan dan santun).

Penilaian sikap yang dilakukan menggunakan empat kategori, yaitu: sangat baik $(3,51$ 4,00), baik (2,51-3,50), kurang baik (1,51-2,50), sangat kurang baik (0,00-1,50). Pada tabel penilaian sikap tidak terdapat kolom deskripsi karakter setiap mahasiswa. Penilaian sikap juga tidak diberikan kepada mahasiswa. Penilaian sikap hanya dituliskan pada DPNA yang 
diserahkan kepada bagian pusat komputer dan kemudian hasil cetakan KHS yang diterima mahasiswa tidak memiliki nilai sikap yang telah dibuat.

\section{b. Data Angket}

Data angket adalah data yang diperoleh dari mahasiswa. Angket yang diberikan bertujuan memperoleh deskripsi mengenai sistem penilaian karakter berdasarkan kesantunan berbahasa mahasiswa. Data angket akan dirincikan pada tabel berikut.

Tabel 1

Persentase Angket Mahasiswa Mengenai Sistem Penilaian Karakter Berdasarkan Kesantunan Berbahasa di Unimed

\begin{tabular}{|l|l|c|c|c|c|}
\hline \multirow{2}{*}{ No. } & \multicolumn{1}{|c|}{ Pernyataan } & \multicolumn{2}{c|}{ Jumlah } & \multicolumn{2}{c|}{ Persentase (\%) } \\
\cline { 3 - 6 } & & Ya & Tidak & Ya & Tidak \\
\hline 1. & $\begin{array}{l}\text { DPNA yang saya terima hanya berisi } \\
\text { penilaian pembelajaran. }\end{array}$ & 54 & 4 & 91.53 & 6.78 \\
\hline 2. & $\begin{array}{l}\text { DPNA yang saya terima berisi } \\
\text { penilaian pembelajaran dan penilaian } \\
\text { kesantunan. }\end{array}$ & 42 & 16 & 71.19 & 27.12 \\
\hline 3. & $\begin{array}{l}\text { Saya menerima lembaran khusus untuk } \\
\text { menilai kesantunan. }\end{array}$ & 16 & 42 & 27.12 & 71.19 \\
\hline 4. & Sikap saya dinilai dalam bentuk angka. & 27 & 30 & 45.76 & 50.85 \\
\hline 5. & $\begin{array}{l}\text { Kesantunan saya dinilai dalam bentuk } \\
\text { deskripsi. }\end{array}$ & 26 & 28 & 44.07 & 47.46 \\
\hline 6. & $\begin{array}{l}\text { Saya pernah mendapatkan lembar isian } \\
\text { mengenai cara menyapa dosen. }\end{array}$ & 15 & 43 & 25.42 & 72.88 \\
\hline 7. & $\begin{array}{l}\text { Saya pernah mendapatkan lembar isian } \\
\text { mengenai cara berbicara dengan dosen. }\end{array}$ & 14 & 44 & 23.73 & 74.58 \\
\hline
\end{tabular}




\begin{tabular}{|l|l|c|c|c|c|}
\hline \multirow{2}{*}{ No. } & \multicolumn{1}{|c|}{ Pernyataan } & \multicolumn{2}{|c|}{ Jumlah } & \multicolumn{2}{c|}{ Persentase (\%) } \\
\cline { 3 - 6 } & & Ya & Tidak & Ya & Tidak \\
\hline 8. & $\begin{array}{l}\text { Saya pernah mendapatkan lembar isian } \\
\text { mengenai cara berbicara dengan teman. }\end{array}$ & 9 & 49 & 15.25 & 83.05 \\
\hline 9. & $\begin{array}{l}\text { Saya pernah mendapatkan lembar isian } \\
\text { mengenai sikap terhadap aturan. }\end{array}$ & 27 & 31 & 45.76 & 52.54 \\
\hline 10. & $\begin{array}{l}\text { Saya pernah mendapatkan lembar isian } \\
\text { mengenai cara mengungkapkan } \\
\text { pendapat. }\end{array}$ & 21 & 37 & 35.59 & 62.71 \\
\hline 11. & $\begin{array}{l}\text { Saya pernah mendapatkan lembar isian } \\
\text { mengenai cara mengungkapkan pujian. }\end{array}$ & 16 & 42 & 27.12 & 71.19 \\
\hline 12. & $\begin{array}{l}\text { Saya pernah mendapatkan lembar isian } \\
\text { mengenai sikap untuk membantu } \\
\text { teman yang mengalami kesulitan. }\end{array}$ & 17 & 41 & 28.81 & 69.49 \\
\hline 13. & $\begin{array}{l}\text { Saya pernah mendapatkan lembar isian } \\
\text { mengenai cara mengucapkan selamat } \\
\text { kepada orang yang lebih berprestasi. }\end{array}$ & 12 & 46 & 20.34 & 77.97 \\
\hline 14. & $\begin{array}{l}\text { Saya pernah mendapatkan lembar isian } \\
\text { mengenai sikap dalam berdiskusi } \\
\text { kelompok. }\end{array}$ & 24 & 34 & 40.68 & 57.63 \\
\hline 15. & $\begin{array}{l}\text { Saya pernah mendapatkan lembar isian } \\
\text { mengenai komitmen dalam berjanji. }\end{array}$ & 19 & 34 & 32.20 & 57.63 \\
\hline 16. & $\begin{array}{l}\text { Saya pernah mendapat lembar isian } \\
\text { mengenai cara berkomunikasi dengan } \\
\text { telepon genggam. }\end{array}$ & 11 & 42 & 18.64 & 71.19 \\
\hline 17. & $\begin{array}{l}\text { Saya pernah mendapatkan lembar isian } \\
\text { mengenai cara menyapa teman. }\end{array}$ & 16 & 37 & 27.12 & 62.71 \\
\hline berkaitan kesantunan berbahasa. & Saya memperoleh hasil penilaian & 26 & 45.76 & 44.07 \\
\hline
\end{tabular}




\begin{tabular}{|l|l|c|c|c|c|}
\hline \multirow{2}{*}{ No. } & \multicolumn{1}{|c|}{ Pernyataan } & \multicolumn{2}{|c|}{ Jumlah } & \multicolumn{2}{c|}{ Persentase (\%) } \\
\cline { 3 - 6 } & \multicolumn{1}{|c}{ Ya } & Tidak & Ya & Tidak \\
\hline 19. & $\begin{array}{l}\text { Saya pernah berdiskusi dengan dosen } \\
\text { berkaitan kesantunan berbahasa kepada } \\
\text { orang lain. }\end{array}$ & 35 & 18 & 59.32 & 30.51 \\
\hline 20. & $\begin{array}{l}\text { Saya pernah berdiskusi dengan dosen } \\
\text { berkaitan cara menuliskan pesan } \\
\text { melalui telepon genggam. }\end{array}$ & 32 & 21 & 54.24 & 35.59 \\
\hline
\end{tabular}

Dari sudut pandang mahasiswa mengenai sistem penilaian karakter berdasarkan kesantunan berbahasa, dapat diketahui bahwa mahasiswa memperoleh DPNA atau KHS yang berisi penilaian pembelajaran $(91,53 \%)$ dan tidak menerima lembaran khusus untuk menilai kesantunan (71.19\%). Selain itu, penilaian khusus mengenai kesantunan berbahasa mahasiswa juga tidak ada. Kurang lebih 50\% mahasiswa menyatakan bahwa mereka tidak pernah mendapat lembar isian yang berisi kesantunan berbahasa. Walaupun begitu, kurang lebih 50\% mahasiswa menyatakan bahwa mereka pernah berdiskusi dengan dosen mengenai cara berbicara dengan orang lain dan menuliskan pesan di telepon genggam.

\section{c. Data Wawancara}

Data wawancara adalah data yang diperoleh dari dosen. Wawancara yang dilakukan untuk memperoleh deskripsi mengenai sistem penilaian karakter berdasarkan kesantunan berbahasa di Perguruan Tinggi. Berdasarkan hasil wawancara dapat diketahui bahwa universitas tidak memiliki penilaian karakter berdasarkan kesantunan berbahasa secara khusus. Universitas hanya memiliki penilaian karakter secara keseluruhan. Nilai-nilai karakter yang dinilai dan diterapkan kepada setiap mahasiswa ada sepuluh, yaitu: etika berkomunikasi (sopan dan santun), kejujuran, tanggung jawab, kerja sama, ketangguhan, kepedulian, kedisiplinan, ketekunan, kemandirian, dan keberinisiatifan. Nilai kesantunan merupakan bagian dari nilai karakter yang telah ditetapkan Unimed, yaitu nilai etika berkomunikasi (sopan dan santun). 
Pemilihan sepuluh nilai karakter sebagai aspek yang dinilai dirancang oleh tim ahli yang ditunjuk. Indikator dari setiap aspek nilai dikembangkan oleh setiap jurusan. Indikator tersebut dikembangkan sesuai dengan mata kuliah yang diajarkan sehingga penilaian yang dilakukan sesuai dengan kebutuhan mata kuliah dan jurusan.

Penilaian sikap yang dilakukan menggunakan empat kategori, yaitu: sangat baik $(3,51$ 4,00), baik (2,51-3,50), kurang baik (1,51-2,50), sangat kurang baik (0,00-1,50). Pada tabel penilaian sikap tidak terdapat kolom deskripsi karakter setiap mahasiswa. Penilaian sikap juga tidak diberikan kepada mahasiswa dan tidak ada diskusi lanjutan pada mahasiswa yang telah dinilai. Penilaian sikap dituliskan pada DPNA yang diserahkan kepada bagian pusat komputer dan kemudian hasil cetakan KHS mahasiswa tidak memiliki nilai sikap yang telah dibuat.

\section{Pembahasan}

Nilai-nilai karakter yang dinilai dan diterapkan di Unimed kepada setiap mahasiswa ada sepuluh, yaitu: etika berkomunikasi (sopan dan santun), kejujuran, tanggung jawab, kerja sama, ketangguhan, kepedulian, kedisiplinan, ketekunan, kemandirian, dan keberinisiatifan. Nilai kesantunan merupakan bagian dari nilai karakter yang telah ditetapkan Unimed, yaitu nilai etika berkomunikasi (sopan dan santun). Pada nilai etika berkomunikasi tidak terdapat penjabaran yang jelas mengenai aspek dan indikator yang perlu dinilai untuk mengamati etika berkomunikasi mahasiswa. Hal tersebut menyebabkan setiap dosen tidak memiliki indikator yang sama dalam menilai kesantunan. Ketiadaan indikator menyebabkan penilaian menjadi tidak reliabel, objektif, dan adil karena setiap dosen tidak memiliki parameter penilaian yang sama. Oleh karena itu, subjektivitas dan ketidakadilan dalam penilaian memiliki kemungkinan untuk terjadi. Hal tersebut juga tidak sesuai dengan prinsip-prinsip penilaian yang menyatakan bahwa penilaian harus reliabel, objektif, dan adil (Widoyoko, 2014, hlm. 16). Melalui penelitian ini, disarankan agar aspek dan indikator penilaian kesantunan berbahasa menggunakan instrument berikut.

Tabel 2

Pedoman Penilaian Karakter Berdasarkan Kesantunan Berbahasa Mahasiswa 


\begin{tabular}{|c|c|c|}
\hline No & $\begin{array}{c}\text { Aspek Kesantunan } \\
\text { Berbahasa }\end{array}$ & Indikator \\
\hline 1. & Kearifan & $\begin{array}{l}\text { - Mahasiswa mampu menilai dan mengambil } \\
\text { keputusan dengan bijaksana. } \\
\text { - Mahasiswa mampu menghadapi segala persoalan } \\
\text { dengan bijaksana. } \\
\text { - Mahasiwa mampu memandang segala sesuatu } \\
\text { dengan kedalaman berfikir. } \\
\text { - Mahasiswa masih menanamkan adat-istiadat } \\
\text { dalam bertutur dan bersikap. }\end{array}$ \\
\hline 2. & Kedermawanan & $\begin{array}{l}\text { - Mahasiswa senang berbagi dengan teman dan } \\
\text { memiliki sifat empati tinggi. } \\
\text { - Mahasiswa senang membantu teman dalam } \\
\text { kesulitan. } \\
\text { - Mahasiswa dapat berpartisipasi dalam kegiatan } \\
\text { amal dan sosial. } \\
\text { - Mahasiswa mencintai alam dan seluruh makhluk } \\
\text { Tuhan }\end{array}$ \\
\hline 3. & Pujian & $\begin{array}{l}\text { - Mahasiswa senang member pujian dan } \\
\text { penghargaan kepada teman. } \\
\text { - Mahasiswa menanggapi setiap pujian dengan } \\
\text { penilaian positif } \\
\text { - Mahasiswa dapat menanggapi setiap pujian yang } \\
\text { mengandung motivasi dengan senang hati. } \\
\text { - Pujian membuat mahasiswa tetap rendah hati. }\end{array}$ \\
\hline 4. & Kerendahan hati & $\begin{array}{l}\text { - Mahasiswa dapat memahami orang lain dan } \\
\text { bersikap rendah hati terhadap orang lain } \\
\text { - Mahasiswa selalu terbuka dengan saran dan } \\
\text { kritikan orang lain. } \\
\text { - Mahasiswa dapat berpikir bahwa setiap orang } \\
\text { memiliki kelebihan dan kekurangan. } \\
\text { - Mahasiswa tidak selalu merasa dirinya paling } \\
\text { benar dan hebat }\end{array}$ \\
\hline 5. & Kesepakatan & $\begin{array}{l}\text { - Mahasiswa dapat membuat kesepakatan bersama } \\
\text { yang tidak merugikan siapapun. } \\
\text { - Mahasiswa selalu dapat menerima kesepakatan } \\
\text { yang sudah dibuat dengan lapang dada. } \\
\text { - Dalam merencanakan sebuah janji, mahasiswa } \\
\text { dapat membuat kesepakatan yang matang. } \\
\text { - Mahasiswa tidak mudah tergoyahkan dari } \\
\text { keputusan yang sudahdibuat. }\end{array}$ \\
\hline 6. & Simpati & - Mahasiswa selalu mencipatkan kenyamanan \\
\hline
\end{tabular}




\begin{tabular}{|c|c|c|}
\hline No & $\begin{array}{c}\text { Aspek Kesantunan } \\
\text { Berbahasa }\end{array}$ & Indikator \\
\hline & & $\begin{array}{l}\text { terhadap orang lain melalui pertolongan dan rasa } \\
\text { empatinya. } \\
\text { - Mahasiswa memberikan contoh yang baik bagi } \\
\text { temannya dalam bertutur dan bersikap. } \\
\text { - Mahasiswa dapat mencitrakan karakter baik dalam } \\
\text { penilaian dosen. } \\
\text { - Mahasiswa dapat mengagumi salah satu dosen } \\
\text { yang menjadi favorit. }\end{array}$ \\
\hline 7. & Pertimbangan & $\begin{array}{l}\text { - Mahasiswa dapat memberikan pilihan pada } \\
\text { sasaran yang tepat. } \\
\text { - Mahasiswa selalu berhati-hati pada setiap tuturan } \\
\text { dan perbuatannya. } \\
\text { - Mahasiswa mampu menilai baik dan buruk atas } \\
\text { perkataan, sikap, dan perbuatannya. } \\
\text { - Mahasiswa dapat mempertim-bangkan keputusan } \\
\text { terbaik saat menghadapi masalah akademik. }\end{array}$ \\
\hline
\end{tabular}

Penilaian karakter yang mengandung kesantunan berbahasa di Unimed menggunakan empat kategori, yaitu: sangat baik (3,51-4,00), baik (2,51-3,50), kurang baik $(1,51-2,50)$, sangat kurang baik $(0,00-1,50)$. Pada tabel penilaian tersebut tidak terdapat kolom deskripsi karakter setiap mahasiswa. Penilaian karakter yang mengandung kesantunan berbahasa di Unimed tidak diberikan kepada mahasiswa. Penilaian tersebut dituliskan pada Daftar Peserta dan Nilai Akhir (DPNA) yang dibuat oleh dosen kemudian diserahkan kepada bagian puskom. Mahasiswa hanya menerima Kartu Hasil Studi (KHS) yang tidak memiliki nilai sikap yang telah dibuat pada DPNA. Tindak lanjut dari penilaian karakter yang mengandung kesantunan berbahasa pada DPNA juga tidak ada dilakukan oleh dosen maupun mahasiswa. Jika ada diskusi berkaitan kesantunan mahasiswa, hal tersebut dilakukan tidak berdasarkan nilai kesantunan yang telah diperoleh dari mahasiswa tersebut. Hal tersebut berbeda dengan prinsip penilaian yang menyatakan bahwa penilaian dilakukan secara terbuka. Keterbukaan yang dimaksud adalah keterbukaan terkait prosedur penilaian, kriteria penilaian, dan dasar pengambilan keputusan yang dapat diakses dan diketahui oleh semua pihak yang mempunyai kepentingan dengan kegiatan penilaian (Widoyoko, 2014, hlm. 16). 
Berdasarkan hal tersebut, sebaiknya sistem penilaian karakter berdasarkan kesantunan berbahasa diubah menjadi lebih sistematis dan terbuka. Sistem penilaian tersebut dapat dilakukan sesuai dengan bagan berikut.

\section{Bagan 2}

Alur Penilaian Sampai Tahap Pembimbingan

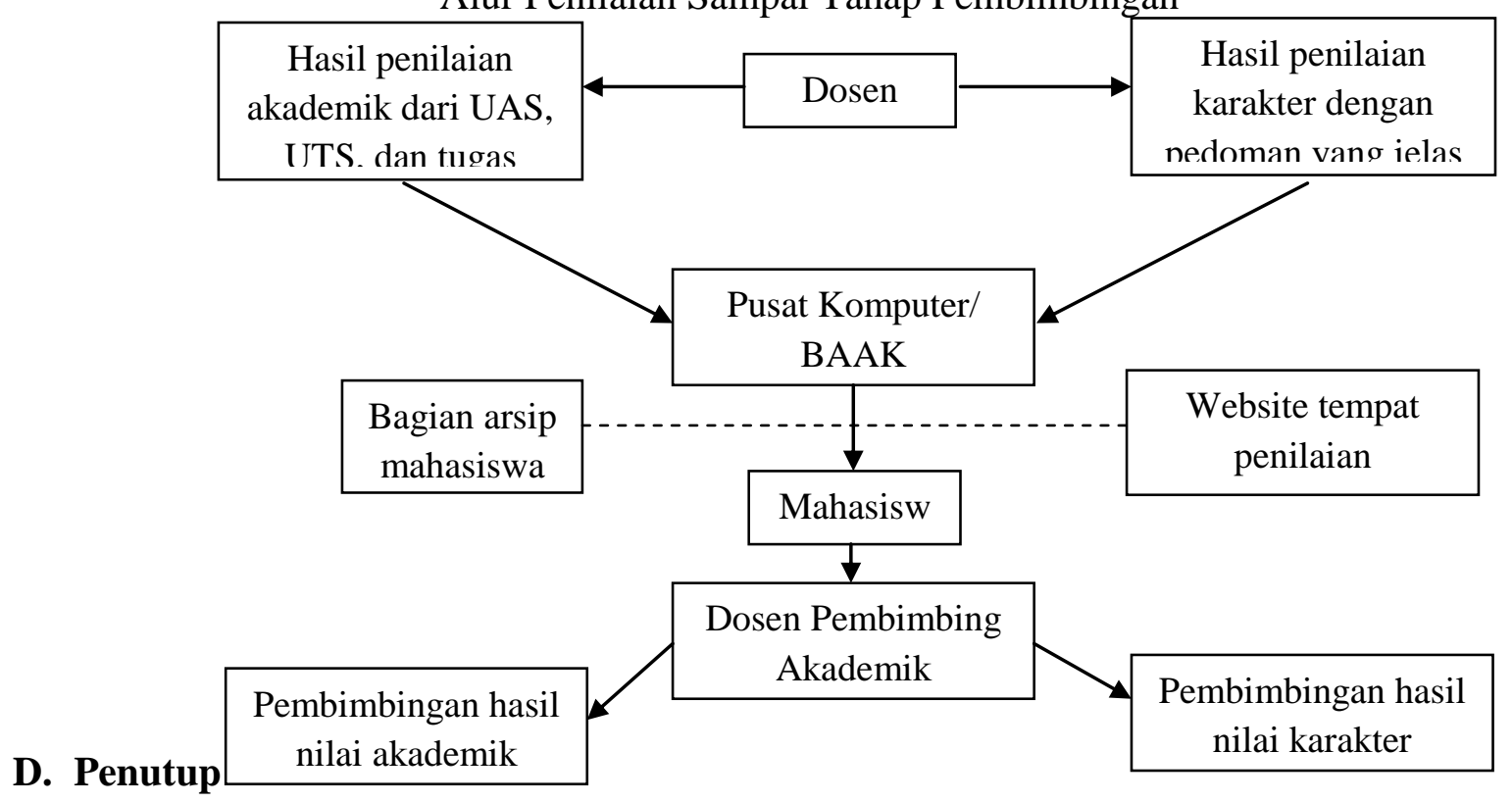

Sistem penilaian merupakan rangkaian unsur atau prosedur yang dirancang untuk menafsirkan atau memaknai data hasil suatu pengukuran berdasarkan kriteria maupun aturanatauran tertentu. Sistem penilaian yang baik juga memilki standar dan aturan yang sama bagi sesuatu yang dinilai, khususnya pada satu universitas. Hal tersebut perlu ditetapkan agar penilaian yang dilakukan lebih reliabel, objektif, dan adil.

Sistem penilaian karakter berdasarkan kesantunan berbahasa sebaiknya terdapat keterbukaan. Prosedur penilaian, kriteria penilaian, dan dasar pengambilan keputusan sebaiknya dapat diakses oleh orang yang berkaitan dengan penilaian. Hasil penilaian juga sebaiknya ditindaklanjuti dengan adanya proses diskusi antara mahasiswa dan dosen agar tujuan penilaian dan evaluasi tercapai.

\section{Daftar Pustaka}


Mulyasa. (2011). Manajemen Pendidikan Karakter. Jakarta: Bumi Aksara.

Nugroho, M. (2015). Kesantunan berbahasa Indonesia sebagai upaya penggunaan bahasa Indonesia yang baik. Universitas Sebelas Maret: Prodi Sastra Indonesia Fakultas Ilmu Budaya.

Kementerian Pendidikan Nasional. (2010). Pengembangan Pendidikan Budaya dan Karakter Bangsa. Bahan Pelatihan Penguatan Metodologi Pembelajaran Berdasarkan Nilai-Nilai Budaya untuk Membentuk Daya Saing dan Karakter Bangsa. Jakarta: Badan Penelitian dan Pengembangan Pusat Kurikulum.

Sauri, S. (2006). Pendidikan berbahasa santun. Bandung: PT. Ganesindo.

Sukardi. (2009). Metodologi penelitian pendidikan: kompetensi dan praktiknya. Jakarta: Bumi Akasara.

Sutanta, E. (2003). Sistem informasi manajemen. Yogyakarta: Graha Ilmu.

Widoyoko, S. E. P. (2014). Penilaian hasil pembelajaran di sekolah. Yogyakarta: Pustaka Pelajar. 